\title{
Gratitude and that which we cannot return: Critical reflections on gratitude
}

\author{
Mees van Hulzen
}

Accepted: 4 March 2021 / Published online: 29 March 2021

(C) The Author(s) 2021

\begin{abstract}
Gratitude is often perceived from the perspective of economic reciprocity, i.e., from the simple logic of quid pro quo. It is for this reason that Marcel Mauss ignores the topic of gratitude in his famous work on gift-giving, and that Seneca believes that gratitude is something which is given in return: 'for the benefit that is accomplished by an act has been repaid by our gratitude if we give it friendly welcome'. In this paper I will demonstrate that gratitude is not something that is given in return or a cancelation of debt. Instead, I will argue for the claim that gratitude is the recognition of that which cannot be returned, which leads, in ideal cases, to a sense of responsibility for the other.
\end{abstract}

Keywords Gratitude $\cdot$ Responsibility $\cdot$ Recognition · Gift-giving · Charity

\section{Introduction}

Gratitude is often perceived from the perspective of economic reciprocity, i.e., from the simple logic of quid pro quo. It is for this reason that Marcel Mauss ignores the topic of gratitude in his famous work on gift-giving (Mauss 2002), and that Seneca believes that gratitude is something which is given in return: 'for the benefit that is accomplished by an act has been repaid by our gratitude if we give it friendly welcome' (Seneca 1935, 121). ${ }^{1}$ In what follows I will demonstrate that gratitude is

\footnotetext{
${ }^{1}$ Seneca's 'economy of gratitude' only applies to beneficial acts. When person A gives $\mathrm{x}$ to person B, B needs to repay the act to A with gratitude, but B still owes A an object of equal value to x (Seneca 1935, 121).
}

M. van Hulzen $(\square)$

Institut für Kulturwissenschaften, Universität Leipzig, Beethovenstraße 6, 04107 Leipzig, Germany

E-Mail: meesvanhulzen@ hotmail.com 
not something that is given in return or a cancelation of debt. Instead, I will argue that gratitude is the recognition of that which cannot be returned, and in ideal cases leads to a sense of responsibility for the other.

The overall structure of this paper is made up by the distinction between two kinds of gratitude: gratitude in exchange and reflective gratitude. The first kind of gratitude will cover the biggest part of this paper. After a brief reflection on how gratitude secures a sense of subjectivity in market exchange, I will discuss at length the role of gratitude in gift exchange. My argument here will be that once we understand that the logic of gift exchange is completely different from the logic of economic reciprocity, we will also see why gratitude cannot be thought of as doing something in return. These two forms of exchange present the positive side of gratitude, but there is also a third form of exchange in which gratitude plays a crucial role and that is charity. It is here that we are first confronted with the dark side of gratitude.

The second kind of gratitude, reflective gratitude, is a further demonstration that gratitude cannot be understood from the perspective of economic reciprocity. This kind of gratitude does not take the form 'A is grateful to B for having given her $x$ '. Instead, gratitude here is primarily directed at 'being' instead of 'doing' and takes the simple form: 'A is grateful that $\mathrm{x}$ '. Also, to this kind of gratitude there is a corresponding dark side.

In the conclusion, I will try to tie these two kinds of gratitude together by arguing that gratitude becomes corrupted the moment it is no longer directed at that which cannot be returned and consequentially no longer leads to a sense of responsibility for the other.

\section{Gratitude in Exchange}

\subsection{Market Exchange}

I will begin with the role of gratitude in the most common form of exchange in our late capitalistic societies, namely that of market exchange. Think here of the way in which you utter the words "thank you" to the cashier of your local drug store. The exchange in such transactions is very straightforward: you tell which product you want to buy; the cashier informs you about the price; you give her the exact amount of money, and the cashier will hand you over the product. These are relatively simple transactions in which it is perfectly clear what it is that the different parties involved owe to each other: in exchange for 10 euro's you can buy one package of aspirins. But what is it that motivates you to say "thank you" once the cashier handed you over the product? Is it the desire to give something in return? But what could it be that is not already returned in the transaction itself? Is it the service that you received?

It indeed, seem to be those market exchanges in which people provide a service for someone else, that people are inclined to express their gratitude. It would for example be a bit strange to write a thank you note after you received a book that you ordered over the internet. But on the other hand, is the service you receive from a pharmacist not also included in the price of the package of aspirins that you 
bought from her? One thing is certain, there is something that escapes the simple back and forth in market exchange. Perhaps the words "thank you" are a token of the fact that a service, how commercial it may be, should never fully be conducted in the abstract language of tit for tat. This is exactly what Simmel means when he, in his wonderful short essay on gratitude, writes that "we do not only thank somebody only for what he does: the feeling with which we often react to the mere existence of a person, must itself be designated as gratitude.' (Simmel 1950, 389). He rightly points out that gratitude forms an antidote against the total reification (Sachwerdung) of human relationships (Simmel 1908: 590). Human relations run the risk of reification when the relation among men is reduced to a relation among objects. Gratitude forms the 'subjective residue' in market exchange and provides a counterbalance to the complete objectification of the relationship (Simmel 1908, 591). ${ }^{2}$

Simmel's take on gratitude is in line with that of Paul Ricoeur who reminds that the French word reconnaissance can be translated both as gratitude and recognition (Ricoeur 2005: 243). Conceiving of gratitude as a form of recognition helps to explain the question why it is that we thank each other even in conducting the smallest transactions. Imagine a situation of exchange in which any expression of gratitude is absent. Think for example of a hostile situation in which people merely cooperate with the other for their own self-interest, such as the exchanges of spies between hostile nations. In these situations, a nod with the head might be sufficient to communicate mutual understanding but the words 'thank you' can be considered to be superfluous. Exchanges in which any form of gratitude is absent are likely to be completely goal orientated and robotic, in which one easily get the feeling of being completely instrumental to one another. From this perspective it is not difficult to think of gratitude as a form of recognition. By expressing our gratitude, we recognize the other not merely as a means, but simultaneously as an end in itself.

One could object that saying thank you is merely an utterance by social etiquette and should be rigorously distinguished from the genuine feeling of gratitude. In everyday life we utter the words thank you on a daily basis, as small ritualistic practices to which we hardly pay any attention, and often are devoid of a sincere feeling of gratitude. Nevertheless, I don't think we can so easily distinguish between practice and intention as certain philosophers might desire. First of all, even when the words thank you are not accompanied by a feeling of gratitude, they still have meaning, even if this is only symbolical. Furthermore, just as it is unlikely that every utterance of thank you is accompanied by a feeling of gratitude, the same holds for the absence of any feeling of gratitude when we say thank you. Feelings like gratitude are embedded in cultural practices and small rituals as saying thank you. When it is demanded of a child to say thank you after having received something, it is not important what the intentions of the child is at the moment it says thank you. What is important is that it develops the custom to say thank you; so that the custom can give the opportunity to feelings of gratitude and prevents us from using the other as a mere means for our own ends.

\footnotetext{
2 Unfortunately, the helpful notion of 'subjective residue' (subjective residuum) is lost in the English translation of K. H. Wolff (Simmel 1950, 288).
} 
This brief reflection on the role of gratitude in market exchange shows us that many of the most instrumental and self-interested relations are not devoid of some sense of gratitude, even though it is merely a dim reflection of a stronger feeling of gratitude.

\subsection{Ceremonial Gift-Giving}

Ceremonial gift exchange, the second form of exchange that I want to discuss here in relation to gratitude, differs radically from that of market exchange. In the latter case, gratitude is directed at that what escapes economic reciprocity. In ceremonial gift exchange, however, gratitude is not complementary to the exchange, but forms a crucial part of the exchange. The role that gratitude has in ceremonial gift exchange has often been neglected or misunderstood. The reason for this is that it has usually been interpreted from the perspective of economic reciprocity as we find it in market exchange. However, as I will argue here, gift exchange has a logic of its own, not of give and take, like in ordinary barter, but rather a form of taking turns or "nonidentical repetition' (Milbank 1995, 125). Once we recognize the fundamentally different logic of gift exchange, we can also see that gratitude is not a form of a return gift or cancellation of debt, but is instead a way in which the recipient obligates herself to the giver.

The debate on ceremonial gift exchange starts with Mauss' small but highly influential book The Gift. In it Mauss distinguishes three duties of gift-giving: the duty to give, the duty to return a gift and the duty to receive (Mauss 2002, 17). ${ }^{3}$ It is especially the second duty, the obligation to return a gift, in which Mauss is mostly interested. The question he tries to seek an answer to is "what compels the gift to be obligatorily reciprocated? What power resides in the object given that causes its recipients to pay it back?' (Mauss 2002, 4). His answer he derives from the Maori in New Zealand who believe that when someone gives a gift, he connects himself somehow to the gift. According to Mauss: 'What imposes obligation in the present received and exchanged, is the fact that the thing received is not inactive. Even when it has been abandoned by the giver it still possesses something of him. Through it the giver has a hold over the beneficiary' (Mauss 2002, 15). This is what is called the 'hau' by the Maori or 'The Spirit of the Gift' (Mauss 2002, 15). Although Mauss is rightly criticized for not distancing himself appropriately from the believes of the Maori $^{4}$, he still provides us with a good metaphor for the way in which the giver holds a certain power over the recipient.

It is interesting that the topic of gratitude is, apart from a few exceptions, completely absent in Mauss' theory of the gift. The reason for this is, that his theory is too much based on an economic model of reciprocity, as has accurately been pointed out by authors like Marcel Hénaff (Hénaff 2002) and Paul Ricoeur (Ricoeur 2005).

\footnotetext{
3 These three duties can also be found many centuries before Mauss wrote The Gift in the work of Seneca when he writes about the three graces or the three sisters: 'one who confer benefits, one who returns them, and one who receives them' (Seneca, 1935, 13).

4 See Lévi-Strauss' Introduction to the Work of Marcel Mauss for a famous critique of Mauss' analyses of the spirit of the gift (Lévi-Strauss 1987). See also Sahlins, Stone Age Economics (1981).
} 
It is especially in the emphasis that Mauss puts on the duty to return a gift that this becomes most apparent. By doing so he makes the gifts themselves the most meaningful element in gift exchange, instead of that what they symbolize. And in addition to that, he neglects the two other principles of giving: first, the duty to give and the corresponding question of the first gift, and second, the duty to receive, and the corresponding question of gratitude.

Simmel, in contrast to Mauss, does discuss the problem of the first gift in his essay on gratitude. It is not a coincidence that he discusses the topics of gratitude and the first gift in the same essay, because both topics are connected to a more asymmetrical understanding of gift exchange. In the model of economic reciprocity that Mauss uses, people exchange gifts and this constitutes equality among the givers as long as they can cancel the debt that is imposed on them by giving a gift in return. However, Simmel rightly points out that there is a problem with this model of reciprocity. According to Simmel, the first gift that is given in a circle of gift exchange, is given in full spontaneity; there is no duty attached to it, not even the duty to show gratitude. This unique characteristic of the first gift makes it that it is impossible to fully reciprocate that what has been given. Although it is rather doubtful whether there is no duty attached to the first gift, it does however seem reasonable to argue that the initiative of the first gift can never be fully reciprocated. The consequence of this is that there always will be a certain imbalance or inequality within gift exchange.

How are we to understand the obligatory character of gift-giving, and more specifically the obligation to return the gift, from this fundamental asymmetry that the first gift creates? Here I would like to follow Hénaff's critique on Mauss. What is crucial for understanding the kind of gifts we have been talking about is that they are given at particular occasions, such as weddings, funerals, birthdays and initiations. Many of these occasions reoccur every year and are part of a particular cultural calendar. The gifts that are exchanged on these occasions are not particularly useful, quite the opposite: it is often their uselessness, their excessive character that makes them especially fit for such occasions, think of chocolate, wine, flowers etc. What is of primary importance is the symbolical value of the gift that is generated in the ceremony of gift-giving. The calendar, customs and traditions determine when ceremonial gifts should be given and by whom, not the gifts themselves as Mauss believed. One might object by pointing to the fact that people have strong memories of what others have given to them. But on the other hand, there also seems to be something wrong if someone would give you a birthday present only because you gave her a present on her last birthday. In such a situation we could say that she did not really get the point of exchanging gifts or birthdays. As Hénaff explains it: 'What matters is not so much giving back, as it is giving in one's turn, not restituting but taking back the initiative in gift-giving. (...) One does not "return" a gift in the way one pays back a loan but in the way one replies to a move' (Hénaff 2002, 139). This presents us with another model of reciprocity, not a symmetrical model in which one gift is received, and another given in return to cancel the debt created by the first gift, but a model of taking turns.

From this it follows that the obligatory character of gift exchange does not consist in the obligation to give a gift in return, but rather in the obligations that come into 
being once you associate with someone. When a gift is given we respond to the gift by expressing our gratitude. In this way we receive the gift. By receiving the gift, we simultaneously recognize the giver and the special relation that the gift seeks to install or reestablish. By recognizing the other and the particular relation the other wishes to establish I commit myself to respond to the needs of the other and the obligations implied in the special relationship. Recognition creates responsibility, once I recognize someone, I make myself responsible for that person, in the sense that I commit myself to respond when that person is in need. This explains why people are reluctant to recognize the other when they do not want to answer to the special needs of that person. Being responsible for something or someone is often reduced to the responsibility that parents have for their children. However, it is hard to imagine the existence of special relations like friendships in which you would not have any commitment to respond to the needs and the actions of the other. This type of responsibility is conditional and complementary to the responsibilities one has for one's own actions and needs, in contrast to the more absolute responsibility for the other in the parent-child relationship.

If we understand the role of gratitude in ceremonial gift-giving in this way it should become clear that gratitude creates obligations, instead of lightening the obligation of the gift, as is for example claimed by Seneca and Ricoeur (Ricoeur 2005, 243). In an influential article Claudia Card has tried to capture this dimension of gratitude by opposing 'the trustee paradigm' to the dominant deontological 'debtor paradigm' (Card 1988). The latter model follows the classical model in which gratitude is understood as a way of paying of the debt that is imposed on you once you received a gift. For Kant it is indeed appropriate to respond to such a debt with gratitude, but it does not lighten de debt. The acceptance of a gift or a favor creates a debt that one cannot pay off, since it is impossible to return the initiative of the first gift. This is why one will always owe a debt of gratitude to the benefactor (Card 1988, 118). Card rightly criticizes the Kantian debtor paradigm for failing to distinguish gratitude from praise. When we are grateful to someone it is because his or her good will was of value to us, not because they simply are praiseworthy (Card $1988,119)$. The debtor paradigm misses out on the way in which gratitude establishes special relationships. Card offers an alternative paradigm that of the 'trustee'. This model is not based on the metaphor of a loan, but of a deposit: 'I can regard myself as the "trustee" of another's good will or concern. I cannot literally return another's good will, but I can reciprocate it.' (Card 1988, 121). In the case of a loan one has the duty to repay, which corresponds to the right of the creditor. In Card's trustee paradigm we have been trusted with something, which creates an obligation, to keep it safe, but it is not an obligation someone can hold me to, like in the case of rights. Rather, in the trustee model one is not treated as a debtor, but as someone who is responsible. This means that it is not merely the beneficiary that is grateful for that what has been placed under her care, but also the benefactor can be grateful in this model to the beneficiary for taking responsibility.

The trustee paradigm is a good attempt at overcoming the problematic debtor paradigm. It clearly shows that gratitude is in particularly relevant in establishing special relations, and how gratitude can be conceived of as installing an obligation in the form of responsibility instead of a cancellation of debt. However, the metaphor 
of a deposit also has its limits, and not just because one favors the other in accepting a deposit or trust, in contrast to simply accepting a favor (Card 1988, 123 -124), but because it focuses, like Mauss, on that what is exchanged instead of on the action of giving. In the case of ceremonial gift-giving we have seen that the gifts and the value they represent are more or less irrelevant, what is important is the way it enables the recognition of the other and the relation it establishes. In the case of Card's trustee paradigm, the responsibility that gratitude acknowledges stems from the thing itself, I am responsible over that which you put under my guardianship, not from the recognition of the other and the relation itself. It is especially on this point that Card's model can be improved by a conception of gratitude based on recognition like that of Simmel and Ricoeur.

\subsection{Charity}

The third form of exchange that I want to discuss here in relation to gratitude is that of charity. It is here that the dark side of gratitude is revealed to us. ${ }^{5}$ I will here only consider forms of charity that reveal to us this dark side of gratitude - bad charity if you like. The hotly debated question in ethics whether gratitude in this or that particular instance is appropriate or not, I will leave unaddressed. What interests me here is how feelings and expressions of gratitude transform under various social conditions, and what these various uses of gratitude reveal about the dynamics of gratitude, in order to develop a more critical understanding of gratitude as a social practice.

Generally, charity is thought of as the practice in which people give aid to those in need, out of compassion, pity or the will to do good. This can be done in the form of money, goods or services. The recipients of charitable gifts, mostly respond to that what they have been given with gratitude. Why is this so? What is exactly the role of gratitude in charitable giving?

Generosity, the other side of gratitude, gives us a first hint. The word generosity comes from the Latin word 'generosus', which means: 'of noble birth', and the stem 'genus' means clan, stock, kin or race and can thus be associated with familial and tribal groups. In reference to charity this reminds us of the famous noblesse oblige, but it should especially make us aware of the link between generosity and leadership. This link is described by various anthropologist and historians, Marshal Sahlins writes for example about generosity as 'usefully enlisted as a starting mechanism for leadership because it creates followership' (Sahlins 1981, 208). This seems to be supported by the fact that when people give to charity they do not do this randomly;

\footnotetext{
5 One might object that charity is not a form of exchange, since charitable gifts are unilateral gifts in which there is nothing given back in return. There is nothing exchanged when a rich businessperson gives a euro to the beggar in the streets. And indeed, if one looks at charity from an everyday perspective if falls out of the domain of exchange. But this is only so if one holds on to what is known as the modern ideology of a pure gift. If one looks at actual practices of charitable giving and the strong demands that are imposed on the recipients of charitable gifts it becomes rather obvious that the ideal of charity is far removed from actual practices of charity. Historically people have defined their social status and bought political power through the means of charity. Often this was accomplished by demanding loyalty and obedience of the beneficiaries.
} 
they critically select, according to a particular ideology, to whom they give and to whom they will not. That generosity is a starting mechanism for leadership seems plausible, but how does this help us to understand the role of gratitude in charitable giving?

Here I believe it is helpful to contrast charity with ceremonial gift exchange. The most crucial difference between both forms of exchange is the status the gift has for the recipient. Within ceremonial gift exchange the gift has predominantly a ceremonial function. It symbolizes the special relation that the giver wants to establish with the recipient. In the case of charity, the gift also has a symbolical function for the benefactor, through it she can define her social status and buy political influence. In cases of charitable giving that is aimed at improving one's social status it is not the recognition of the beneficiary that is most important for the benefactor, but rather, how her aid is conceived of by her peers. For a recipient that is pushed by the necessities of life to accept the aid, it is however, the material value of the gift that has priority. In ceremonial gift exchange, gratitude is an answer to a particular relation and the responsibilities that the particular relation implies. However, in the case of charity the beneficiary cannot afford to be too selective, let alone carry a sense of responsibility for the giver. Gratitude is here likely to become merely an expression of obedience. What makes charity so humiliating is not per se that it creates obligations, but that it subjects someone to the arbitrary will of the other. As we can see here it are the necessities of life that corrupt the gift relation, and as Michael Walzer puts it: 'concedes the power of the powerful and forces the poor into the position of beggars' (Walzer 2011, 74).

What makes gratitude especially dark in charitable giving is the way in which the expression of gratitude is a form of subjectivation in the Foucauldian sense. By which I mean that gratitude becomes an expression of surrender to- and internalization - of the will of the benefactor. This is enforced because we limit our critical judgement when we respond to the other by expressing our gratitude. This is demonstrated by the taboo that lies on the questioning of a gift, as is for example illustrated by wellknown expressions like: 'Don't look a gift horse in the mouth' or 'Never bite the hand that feeds you'. In so far as the benefactor gives with a gift, a part of herself, it is not just the gift which, with help of the strong taboo on ingratitude, is immune to critical reflection but also the benefactor herself. In this sense the expression 'don't look a gift horse in the mouth' is not limited to the horse but extends to the giver of the horse.

Like in the two previous forms of exchange, the recipient recognizes the giver by expressing his gratitude. In the case of charity, however, the pressing conditions of the recipient make it that the recognition of the giver, turns into a complete surrender to the arbitrary will of the giver, and what makes matters worse is that gratitude is not only a confirmation of debt, but simultaneously impedes the beneficiary to question his benefactor and the debt that is imposed on him. 


\section{Reflective Gratitude}

So far, I have only discussed gratitude in various forms of exchange. Here gratitude always takes the form: 'A is grateful to B for having given her X'. In these exchanges, gratitude is always caused by a gift or a service offered by someone else. But, we are not only grateful when things are intentionally given to us, sometimes we are simply grateful for things being the way they are. We can for example imagine someone who is sincerely grateful that it is good weather the day she is having a picnic. This is obviously not something that is intentionally given to her, but still she can experience a sincere sense of gratitude. Gratitude is here not only directed at nonagents, we can also think of someone who is grateful for her friend being the way she is.

This kind of gratitude can be called reflective gratitude. Why reflective? Because it is the kind of gratitude that is not a direct response to something that is intentionally given to us, but rather it is the kind of gratitude we feel when we reflect upon our own being and that of other beings, and take pleasure in their existence. It is the kind of gratitude we feel when we realize that things could have been different, that the world in which we live today can be a different one tomorrow.

In most philosophical treatments this kind of gratitude is left out of account. Most philosophers, direct their attention exclusively on what they think that people ought to do rather than on 'being'. But there are also a number of philosophers, like Sean McAleer (McAleer 2012) and Patrick Fitzgerald (Fitzgerald 1998) who form an exception. Sometimes the importance given to this second kind of gratitude results in the oversimplification of the first kind. This is unfortunate, since it misses out on the link between both kinds of gratitude. Reflective gratitude, like gratitude in exchange, is also directed at that which cannot be returned, only this characteristic of gratitude loses its relevance outside of the domain of exchange. It is the kind of gratitude that is furthest away from being a means of exchange or the cancelation of debt. In some cases, reflective gratitude might even inspire to a first gift and consequentially to the obligations that arise within gift relationships.

Reflective gratitude does not answer a question in the way that gratitude in gift exchange answers to a question. Reflective gratitude is silent, it is far removed from the noisy world of exchange. This is probably the reason why it is not so often noticed by philosophers who are exclusively drawn to the light of the public sphere. In many instances when people will feel a sense of reflective gratitude they don't have the urge to communicate this to others, except in poetry and art perhaps. It restrains our tendency to alter the world around us according to our needs, and is essentially an affirmation of something or someone's being. It is a form of gratefulness that takes the form of 'letting go'. McAleer rightly points out that this kind of gratitude is a form of humility that offers us a sense of self-knowledge, in so far as it helps us to positively relate to the conditions of our own finitude (McAleer 2012, 59).

The non-responsiveness of reflective gratitude forms its beauty but also constitutes its dark side. In the case of charity, we saw that it is the recipient of charity that cannot respond to the subjectivity of her benefactor, in so far as the benefactor does not seek the recognition of the beneficiary through the offering of a charitable gift. Not in any sense is the beneficiary asked to feel responsible for her benefactor in 
the way in which friends, for example, feel responsible for each other. In reflective gratitude there is also a sense of non-responsiveness, not because the necessities of life stand in the way of the full recognition of the other. On the contrary, in the case of reflective gratitude it is the absence of necessity which makes it that the feeling of gratitude does not translate itself into a sense of responsibility for the other. Things are good as they are, why respond to them or let alone carry a sense of responsibility for them?

Reflective gratitude is often described as a sense of humility, as already mentioned, and like in the case of charity a central part of this humility is receiving without questioning. Think for example of the lyrical, semi-pantheistic poetry of Walt Whitman, that is often quoted by those who want to describe this form of gratitude. ${ }^{6}$ In his poetry he celebrates the world that is, and in order to do that he has to refrain from critical judgment; the thief, the lover, the soldier and the beggar are all equally beautiful for him. Fitzgerald gives another example, that of the Dalai Lama, who expresses his gratitude towards his oppressors when he states: 'because of the Chinese threats and humiliations I have become a real person' (Fitzgerald $1998,124)$. In its most extreme forms reflective gratitude leads to a sense of wordlessness. To affirm that what is can only be done if we do not distinguish the one from the other. This is the reason that reflective gratitude in its most extreme forms has to refrain from having particular obligations and responsibilities towards the other. See here the sharp contrast with the role of gratitude in ceremonial gift exchange in which gratitude is an expression of saying yes to a particular social bond and to the obligations and responsibilities that go with it. Not to hold on to one in exclusion of the other, but to feel grateful for the world as it presents itself to us, leads ultimately to a sense of indifference in which the value of one thing can no longer be distinguished from the value of something else. Note that there is a link here with charity as the ideal of universal love as pursued by various monastic traditions who tend to be reticent when it comes to special relations.

Nevertheless, reflective gratitude does not need to end up in such a dark place of complete indifference. When someone reflects on her own life she can feel a sense of gratitude for the things that she has received, and this can lead to the incentive to give something in her own turn. Take for example someone who might feel a sense of gratitude for the care she has received from her parents. This is something that cannot be returned, since she will never be the parent of her parents, but it can inspire her in what she gives to her own children. In such moments of reflective gratitude someone does not feel the obligation to repay what she has been given, but rather to give in her own turn, to pass on what she has been given. Here we see how gratitude can also inspire to the initiative to give.

\footnotetext{
6 See, for example, Lewis Hyde's The Gift: Creativity and the Artist in the Modern World, Chap. 9: A draft on Whitman (2009).
} 


\section{Conclusion}

I like to conclude with a comment on gratitude and obligations. As already mentioned, when gratitude is discussed, many philosophers direct their attention to the question whether or not and under which circumstances we have the duty to be grateful. I believe this not to be a very productive approach. To conceive of gratitude in this way reduces gratitude to a means of exchange. As I argued above, it is the model of economic reciprocity that is responsible for this conception of gratitude. It fails to perceive gratitude as a form of recognition of that which cannot be returned. On the basis of gratitude in ceremonial gift-giving I have tried to offer a different approach to gratitude, one in which gratitude is conceived of as an expression and recognition of the other. This creates certain obligations and responsibilities in so far as gratitude here is the acceptance of a particular relation to the other. Gratitude becomes corrupted the moment that it loses this sense of responsibility. In the case of charity this happens because the dire need of the recipient turns the obligations of responsibility into obligations of obedience. And in the case of extreme reflective gratitude it is, on the contrary, the absence of necessity that prevents gratitude from creating a sense of responsibility.

Funding Open Access funding enabled and organized by Projekt DEAL.

Open Access This article is licensed under a Creative Commons Attribution 4.0 International License, which permits use, sharing, adaptation, distribution and reproduction in any medium or format, as long as you give appropriate credit to the original author(s) and the source, provide a link to the Creative Commons licence, and indicate if changes were made. The images or other third party material in this article are included in the article's Creative Commons licence, unless indicated otherwise in a credit line to the material. If material is not included in the article's Creative Commons licence and your intended use is not permitted by statutory regulation or exceeds the permitted use, you will need to obtain permission directly from the copyright holder. To view a copy of this licence, visit http://creativecommons.org/licenses/by/4. $0 \%$.

\section{References}

Card, Claudia. 1988. Gratitude and Obligation. American Philosophical Quarterly, 25 - 2: 115 - 127.

Fitzgerald, Patrick. 1998. Gratitude and Justice. Ethics, 109 - 1: 119 - 153.

Hénaff, Marcel. 2002. The Price of Truth. Trans. Jean-Louis Morhange. California: Stanford University Press.

Hyde, Lewis. 2009. The Gift: Creativity and the Artist in the Modern World. New York: Vintage Books.

Lévi-Strauss, Claude. 1987. Introduction to the Work of Marcel Mauss. Trans. Felicity Baker. London: Routledge \& Kegan Paul.

Mauss, Marcel. 1924/2002. The Gift: The Form and Reason for Exchange in Archaic Societies. Trans. W.D Halls. London: Routledge Classics.

McAleer, Sean. 2012. Propositional Gratitude. American Philosophical Quarterly, 49 - 1: 55 - 66.

Milbank, John. 1995. Can a Gift be Given? Modern Theology, 11 - 1: 119 - 161.

Ricoeur, Paul. 2005. The Course of Recognition. Trans. David Pellauer. Cambridge: Harvard University Press.

Sahlins, Marshal. 1981. Stone Age Economics. London: Tavistock Publications Ltd.

Seneca. 1935. On Benefits. Trans. John W. Basore. Cambridge: Harvard University Press.

Simmel, Georg. 1908. Exkurs über Treue und Dankbarkeit. Soziologie: Untersuchungen über die Formen der Vergesellschaftung. Leipzig: Verlag von Duncker Humblolt.

Simmel, Georg. 1950. Faithfulness and Gratitude. In The Sociology of Georg Simmel. Ed. \& trans. Kurt H. Wolff. Glencoe, Illinois: The Free Press.

Walzer, Michael. 2011. On Humanitarianism. On Foreign Affairs, 90 - 4: 69 - 80. 